\title{
Safranbolu İlçesindeki Konaklama İşletmelerinin Finansal Sorunları Üzerine Bir Araştırma ${ }^{1}$
}

\section{A Research on Financial Problems of Accommodation Enterprises in Safranbolu District}

\author{
Hasan UYGURTÜRK* \\ Cenk ÇETINKAYA **
}

\begin{abstract}
$\ddot{O} Z$
Ekonomik kalkınmada önemli rol üstlenen turizm sektörünün ana unsurlarında biri konaklama işletmeleridir. Yoğun rekabet ortamında faaliyet gösteren konaklama işletmeleri var olmak ve büyüyebilmek için sağllklı ve güçlü bir mali yapıya sahip olmalıdır. Ancak konaklama işletmeleri faaliyetleri süresince birtakım finansal sorunlarla yüzleşmek zorunda kalmaktadır. Bu çallşmada, Türkiye'de turizm sektöründe önemli bir yere sahip olan Safranbolu ilçesinde faaliyet gösteren konaklama işletmelerinin finansal sorunlarının tespit edilmesi amaçlanmıştır. Bu amaç doğrultusunda Safranbolu'da yer alan konaklama ișletmelerinde anket çalıșması yapılmıș ve elde edilen veriler analiz edilmiştir. Çalışma sonucunda Safranbolu'daki konaklama işletmelerinin slklkkla karşılaşttkları finansal sorunların kapasite düşüklü̈̆̈̈, yüksek personel ve sigorta giderleri, kar marjlarının düşük olmasl, özsermaye yetersizliği, kisıtlı kredi imkanlarl, yüksek vergi ve harçlar ile sektörel teşviklerin yetersizliği olduğu tespit edilmişstir.
\end{abstract}

\section{ANAHTAR KELIMELER}

Konaklama İşletmeleri, Finansal Sorunlar, Safranbolu

\begin{abstract}
One of the main components of the tourism sector, which plays an important role in economic development, is accommodation enterprises. Accommodation enterprises operating in intense competition environment should have a healthy and strong financial structure in order to exist and grow their assets. However, accommodation enterprises have to face some financial problems during their activities. In this study, it is aimed to determine the financial problems of accommodation enterprises operating in Safranbolu, which has an important place in the tourism sector in Turkey. For this purpose, a questionnaire study was applied to the accommodation enterprises in Safranbolu and the obtained data were analyzed. As a result of the study, it is determined that the financial problems faced by the accommodation enterprises in Safranbolu frequently are low capacity, high personnel and insurance costs, low profit margins, lack of equity capital, limited credit facilities, high taxes and fees, and inadequate sectoral incentives.
\end{abstract}

\section{KEYWORDS}

Accommodation Enterprises, Financial Problems, Safranbolu

\begin{tabular}{|c|c|c|}
\hline \multicolumn{2}{|c|}{ Makale Geliş Tarihi / Submission Date } & \multicolumn{1}{c|}{$\begin{array}{c}\text { Makale Kabul Tarihi / Date of Acceptance } \\
\text { 02.09.2019 }\end{array}$} \\
\hline \multirow{3}{*}{ Atıf } & \multicolumn{2}{|c|}{$\begin{array}{l}\text { Uygurtürk, H. ve Çetinkaya, C. (2019). Safranbolu İlçesindeki Konaklama İşletmelerinin Finansal Sorunları Üzerine } \\
\text { Bir Araştırma. Selçuk Üniversitesi Sosyal Bilimler Meslek Yüksekokulu Dergisi, 22 (2), 758-773. }\end{array}$} \\
\hline
\end{tabular}

\footnotetext{
${ }^{1}$ Bu makale, Cenk Çetinkaya'nın Karabük Üniversitesi, Sosyal Bilimler Enstitüsü, İşletme Anabilim Dalı’nda kabul edilen yüksek lisans tezinden türetilmiştir.

* Doç. Dr., Karabük Üniversitesi, İşletme Fakültesi, Girişimcilik Bölümü, hasanuygurturk@karabuk.edu.tr, ORCID: 0000-0002-9252-0155

** Doktora Öğrencisi, Nevşehir Hacı Bektaş Veli Üniversitesi, Sosyal Bilimler Enstitüsü, Üretim Yönetimi ve Pazarlama Anabilim Dalı, cenkcetinkaya78@hotmail.com, ORCID: 0000-0001-9620-3598
} 


\section{GİRIŞ}

Sürekli değişen dinamik bir ekonomik ortamda faaliyette bulunan işletmeler çeşitli sorunlarla yüzleşmek durumunda kalmaktadırlar. Karşılaşılan sorunların tespiti ve bunlara çözüm önerileri geliştirmek işletme yöneticilerinin zamanlarını alan önemli konuların başında gelmektedir. Yöneticilerin muhatap oldukları sorunların bazıları duruma özel olsa da çoğu sorun farklılaşan zamana ve müşteri tercihine bağlı olarak farklı şekillerde tekrarlanmaktadır. Söz konusu sorunlardan biri olan ve hemen hemen tüm işletmelerde karşılaşılan önemli sorunlardan birini finansal nitelikli sorunlar oluşturmaktadır. Finansal sorunların sıklıkla karşılaşıldığı sektörlerden biri de turizmdir.

Turizm, ülkelerin döviz girdisini artırmakla beraber istihdama da önemli katkı sağlayarak ekonomik gelişmeye ivme kazandırmaktadır. Ayrıca turizm ülkelerin doğal, tarihi, arkeolojik verilerine değer katan ve uluslararası alanda ülkelerin birbirlerine yakınlaşmasını sağlayan en önemli sektörlerden biri konumunda bulunmaktadır (Ünüvar, 2006:180).

Turizm sektörünün başlica unsurlarından biri turizm işletmelerdir. Yoğun rekabet ortamında bulunan turizm işletmeleri faaliyetlerinin sürekliliğini sağlayabilmek için ihtiyaç duydukları fonları uygun koşullarda elde edip bu fonları en iyi şekilde kullanabilmelidirler. Turizm sektöründeki ana işletme gruplarından biri olan konaklama işletmeleri için de sağlıklı bir finansal yapıya sahip olmak önem arz etmektedir.

Konaklama işletmelerinin maliyetlerinin önemli bir bölümü yatırım maliyetlerinden oluşmaktadır. $\mathrm{Bu}$ işletmelerin faaliyet sürecinde ise iş gücü maliyetleri, yiyecek-içecek maliyetleri ile konaklama hizmetlerine ilişkin maliyetler temel gider kalemlerini oluşturmaktadır (Türksoy, 2007: 109). Sabit sermaye yatırımlarının yüksek olması, uzun vadeli fon bulmada yaşanan problemler ve desteklerden yeterince yararlanılamaması otel işletmelerinin finansal anlamda dikkatli olmalarının gerekliliğini ortaya çıkarmaktadır. Özellikle mevsimsel koşulların daha çok etki ettiği turistik hareketlerin yoğun olarak yaşandığı bölgelerde turizm işletmelerinin finansal sorunları daha çok göze çarpmaktadır. Turistik talebin değişken yapısı da bu işletmelerin finansal planlama yapmalarını zorlaştırarak finansal sorunlara neden olmaktadır. Turizm işletmeleri finansal piyasaları takip ederek ve iyi bir finansal yönetim stratejisi uygulayarak yaşanabilecek finansal sorunların üstesinden gelebilmelidir (Akınc1, 2016: 144; Kaşlı ve Karataban, 2008: 145).

Turizm sektöründe faaliyet gösteren işletmelerin doğru finansman kaynaklarını kullanmaları, sağliklı ve güçlü bir mali yapıya sahip olmaları hem işletmenin kendisi hem de faaliyet gösterdiği turizm destinasyonun gelişimi açısından önem taşımaktadır. Bu kapsamda sahip olduğu konaklama işletmeleri, tarihi, doğal güzellikleri ve sosyo-kültürel özellikleri ile ön plana çıkan turizm destinasyonlarından biri de Safranbolu'dur.

$\mathrm{Bu}$ çalışmada konaklama işletmelerinin finansal sorunlarının tespit edilmesi amaçlanmıştır. $\mathrm{Bu}$ amaç doğrultusunda önemli turizm destinasyonlarından biri olan Safranbolu'da yer alan konaklama işletmeleri çalışma kapsamına alınmıştır. Sürekli gelişen ve büyüyen turizm ekosistemi içinde faaliyet gösteren konaklama işletmelerinin finansal sorunlarının tespiti turizm sektörünün sağlıklı gelişimi açısından da önem arz etmektedir. Dolayısıyla konaklama işletmelerinin finansal sorunlarını tespit etmek işletme yöneticilerine 1şık tutabileceği gibi diğer akademik nitelikli çalışmalara da fikir sunacaktır. Ayrıca araştırma sonuçları çerçevesinde tespit edilen finansal sorunların çözüme kavuşturulmasıyla konaklama işletmelerinin etkinliklerinin artacağı düşünülmektedir.

\section{LITERATÜR ARAŞTIRMASI}

Konaklama işletmelerinin yaşadığı finansal sorunların belirlenmesine yönelik farklı araştırmacılar tarafından yapılan çalışmalardan bazıları aşağıda yer almaktadır.

Ceylan ve İlban (2005) Balıkesir'de faaliyet gösteren otel işletmelerinin finansal sorunlarını ve uyguladıkları finansal teknikleri araştırmışlardır. Araştırma sonucunda otel işletmelerinin en önemli finansal sorunlarının nakit para sıkıntısı, tahsilatların zamanında yapılamaması ve maliyetlerdeki artışlar olduğu belirlenmiştir. Yılmaz (2007), Bodrum'daki konaklama işletmelerinin finansman sorunları ile uygulamalarını saptamayı ve bunlara çözüm önerileri getirmeyi amaçlamıştır. Yılmaz, işletmelerin en önemli sorununun finansman sorunu olduğunu ve bunu sırasıyla personel ve pazarlama sorunlarının takip ettiğini ifade etmiştir. İşletmelerin karşılaştığı finansman sorunlarının başında ise "kredi temininde zorluklar" ve "kredi maliyetlerinin yüksek olması" geldiğini belirtmiştir. Sanjeev vd. (2012) çalışmalarında Hindistan'daki konaklama sektöründe karşılaşılan finansal sıkıntıların belirlenmesini ve bunlara çözüm önerisi getirmeyi amaçlamışlardır. Çalışmada, Hindistan' daki konaklama sektöründe karşılaşılan başlıca finansal sıkıntıların yüksek finansman maliyetleri, vergi çeşitliliğgi, işletme sermayesi sorunları ile lisanslama ve yasalarla ilgili konular olduğu vurgulanmıştır.

Bilen vd. (2014) araştırmalarında Diyarbakır'daki konaklama işletmelerinin yaşadığı finansman problemlerinin tespit edilmesini ve söz konusu problemlerin çözümüne yönelik öneriler sunmayı 
amaçlamışlardır. 22 konaklama işletmesinin kapsama alındığ çalışmada işletmelerin finansman teminindeki en önemli problemlerinin kredi teminindeki zorluklar ve çalışma sermayesinin azalması olduğu belirlenmiştir. Akay vd. (2015) çalışmalarında turizm işletmelerinin finansal sorunlarını tespit etmek ve çözüm önerilerini ortaya koymayı amaçlamışlardır. Yetersiz kazançlar, yüksek girdi maliyetleri ve nakit açığı turizm işletmelerinin en önemli finansal sorunları olarak sıralanmıştır. Karadeniz vd. (2015), Van'da bulunan KOBİ statüsündeki konaklama işletmelerinin ve A grubu seyahat acentalarının finansal sorunlarının analiz edilmesini amaçlamışlardır. 24 konaklama işletmesi ile 12 adet seyahat acentasının analize dahil edildiği çalışma sonucunda konaklama işletmelerinin ve seyahat acentalarının en önemli finansal sorunlarının enerji giderleri, vergi oranları ve faiz oranlarının yüksekliği olduğu ifade edilmiştir. Karadeniz vd. (2018) çalışmalarında Erzurum ve Kars'da bulunan KOBİ niteliğindeki otel işletmelerinin finansal sorunlarının analiz edilmesini amaçlamışlardır. 52 otel işletmesinden elde edilen veriler doğrultusunda otel işletmelerinin genel olarak finansal sorunlarının maliyetlerin değişkenliği, bankaların sundukları ağır şartlar, vergi ve faiz oranlarının yüksekliği gibi sorunlar olduğu ifade edilmiştir.

\section{2. ÇALIŞMANIN KAPSAMI VE YÖNTEM}

Bu çalışmada konaklama işletmelerinin finansal sorunlarının tespit edilmesi amaçlanmış ve turizm sektörü için önemli destinasyonlardan biri olan Safranbolu'da yer alan konaklama işletmeleri çalışma kapsamına alınmıştır. Konaklama işletmelerinin sağlıklı bir mali yapıya sahip olması ve finansal açıdan etkin bir şekilde faaliyetlerini sürdürmesi hem kendisi hem de içinde bulunduğu şehrin ekonomisi açısından önem taşıdığından üzerinde dikkatle durulması gereken bir konudur.

Araştırmanın ana kütlesini Safranbolu ilçesindeki konaklama işletmelerinde çalışan yetkili kişiler oluşturmaktadır. Kültür ve Turizm Bakanlığı'na bağlı Safranbolu Turizm Danışma Bürosu'ndan edinilen bilgilere göre 2017 yılı itibariyle Safranbolu'da turizm işletme belgeli 26, belediye belgeli 95 toplamda 121 konaklama işletmesi bulunmaktadır (STDB, 2019). Konaklama işletmelerinin tamamına ulaşılmış ancak 76 işletme yetkilisi ankete katılmayı kabul etmiştir. Anketlerden eksik veri içerenler (soruların tamamına cevap verilmeyenler) ve doğru doldurulmayanlar analiz dışı bırakılmıştır. Sonuç olarak toplam 62 anket analiz amacıyla değerlendirmeye alınmış ve analize dahil edilmiştir.

Çalışmada konaklama işletmelerinde karşılaşılan finansal sorunların tespitine yönelik veri toplamak amacıyla anket yöntemi kullanılmıştır. Anket formu iki bölümden oluşmaktadır. Birinci bölümde konaklama işletmelerinin özelliklerini tespit etmeye yönelik sorular bulunmaktadır. İkinci bölümde ise fonksiyonel bilgiler adı altında işletmelerin finansal sorunlarını tespit etmeyi amaçlayan 21 soru yer almaktadır.

Çalışma kapsamında konaklama işletmelerinde karşılaşılan finansal sorunları tespit etmek amacıyla, daha önce literatürde kullanılan ölçekler incelenmiş ve araştırma konusuna uygun olduğu düşünülen ölçekler anket formunda kullanılmıştır. Beşli likert tipi ölçeğin kullanıldığı anket formunda ölçek maddeleri "1= Önemsiz", " $2=$ Biraz Önemli", " $3=$ Önemli", " $4=$ Oldukça Önemli" ve " $5=$ Çok Önemli" şeklinde belirlenmiştir. Safranbolu' daki konaklama işletmelerinin finansal sorunlarını tespit edebilmek amacıyla oluşturulan anketten elde edilen veriler ile frekans analizi yapılmış ve ortalamalar üzerinden yorumlanmıştır. Frekans analizi için SPSS programından yararlanılmıştır.

\section{BULGULAR}

Bulgular başlığı altında Safranbolu'da yer alan ve çalışmaya dahil olan konaklama işletmelerine ait bilgiler ile çalışma kapsamında gerçekleştirilen analiz sonuçlarına yer verilmiştir. Araştırmaya dahil edilen konaklama işletmelerine istatistiki bilgiler Tablo 1'de gösterilmiştir. 
Tablo 1: Konaklama İşletmelerine Ait İstatistiki Bilgiler

\begin{tabular}{|c|c|c|c|}
\hline \multicolumn{2}{|l|}{ Değișken } & \multirow{2}{*}{$\frac{\text { Sayı }(\mathbf{N})}{13}$} & \multirow{2}{*}{$\begin{array}{c}\text { Yüzde (\%) } \\
21,0\end{array}$} \\
\hline \multirow{5}{*}{ Konaklama işletmesinin türü } & Otel & & \\
\hline & Motel & 0 & 0 \\
\hline & Butik Otel & 30 & 48,4 \\
\hline & Pansiyon & 16 & 25,8 \\
\hline & Diğer (Konak, bağ evi vb.) & 3 & 4,8 \\
\hline \multirow{2}{*}{$\begin{array}{l}\text { Konaklama işletmesinin belge } \\
\text { durumu }\end{array}$} & Belediye Belgeli & 35 & 56,5 \\
\hline & Turizm Bakanlığı Belgeli & 27 & 43,5 \\
\hline \multirow{5}{*}{ Konaklama işletmenin hukuki yapısı } & Şahıs Şirketi & 43 & 69,4 \\
\hline & Kollektif Şirket & 0 & 0 \\
\hline & Limited Şirket & 12 & 19,4 \\
\hline & Anonim Şirket & 4 & 6,5 \\
\hline & Diğer & 3 & 4,8 \\
\hline \multirow{4}{*}{$\begin{array}{l}\text { Konaklama işletmesinin faaliyet } \\
\text { süresi }\end{array}$} & $1-5 \mathrm{y} 11$ & 19 & 30,6 \\
\hline & $6-10 \mathrm{y} 11$ & 21 & 33,9 \\
\hline & $11-15$ y1l & 14 & 22,6 \\
\hline & 16 y1l ve üstü & 8 & 12,9 \\
\hline \multirow{5}{*}{$\begin{array}{l}\text { Konaklama işletmesindeki yatak } \\
\text { sayısı }\end{array}$} & 1-10 yatak & 14 & 22,6 \\
\hline & 11-20 yatak & 21 & 33,9 \\
\hline & 21-30 yatak & 12 & 19,4 \\
\hline & 31-40 yatak & 4 & 6,5 \\
\hline & 41 yatak ve üstü & 11 & 17,7 \\
\hline \multirow{4}{*}{$\begin{array}{l}\text { Konaklama İşletmesindeki personel } \\
\text { sayısı }\end{array}$} & 1-9 kişi & 53 & 85,5 \\
\hline & 10-20 kişi & 5 & 8,1 \\
\hline & 21-30 kişi & 2 & 3,2 \\
\hline & 31 kişi ve üstü & 2 & 3,2 \\
\hline \multirow{2}{*}{$\begin{array}{l}\text { Konaklama işletmesinde finansman } \\
\text { bölümü var mı? }\end{array}$} & Evet & 16 & 25,8 \\
\hline & Hayır & 46 & 74,2 \\
\hline \multirow{4}{*}{$\begin{array}{l}\text { Konaklama işletmesinde finans } \\
\text { yönetimi görevi kim tarafından } \\
\text { yürütülmektedir? }\end{array}$} & Patron/İşletme Sahibi & 45 & 72,6 \\
\hline & $\begin{array}{l}\text { Finans Müdürü/ Finansman } \\
\text { Bölümü }\end{array}$ & 4 & 6,5 \\
\hline & $\begin{array}{l}\text { Muhasebe Müdürü/ } \\
\text { Muhasebe Bölümü }\end{array}$ & 6 & 9,7 \\
\hline & Diğer & 7 & 11,3 \\
\hline \multirow{2}{*}{$\begin{array}{l}\text { Konaklama işletmesinde finansal } \\
\text { planlama yapilıyor mu? }\end{array}$} & Evet & 31 & 50,0 \\
\hline & Hayır & 31 & 50,0 \\
\hline \multirow{2}{*}{$\begin{array}{l}\text { Konaklama işletmesinde faaliyetler } \\
\text { için özsermaye yeterli mi? }\end{array}$} & Evet & 47 & 75,8 \\
\hline & Hayır & 15 & 24,2 \\
\hline \multirow{9}{*}{$\begin{array}{l}\text { Konaklama işletmesinde mevcut } \\
\text { faaliyetler hangi kaynaklardan } \\
\text { finanse edilmektedir? }\end{array}$} & Şirket Karı & 41 & 66,1 \\
\hline & Banka Kredisi & 12 & 19,4 \\
\hline & Faktoring & 0 & 0 \\
\hline & Finansal Kiralama & 0 & 0 \\
\hline & Teşvikler & 0 & 0 \\
\hline & Yeni ortaklar & 0 & 0 \\
\hline & Satıcı Kredisi & 0 & 0 \\
\hline & Eş dosttan borç alma & 0 & 0 \\
\hline & Özsermaye & 9 & 14,5 \\
\hline
\end{tabular}


Tablo 1'e göre konaklama işletmelerinin \%48,4'ünü (30 adet) "Butik Otel”, \%25,8'ini (16 adet) "Pansiyon", \%21'ini (13 adet) "Otel” ve son olarak \%4,8'ini (3 adet) "Diğer" işletmeler (konak, bağ evi vb.) oluşturmaktadır. Sahip olunan belge açısından incelendiğinde işletmelerin \%56,5'ini (35 adet) "Belediye Belgeli" işletmeler, \%43,5'ini (27 adet) "Turizm Bakanlığ 1 Belgeli" işletmeler oluşturmaktadır. İşletmeler hukuki yapılarına göre ele alındığında 43 "Şahıs Şirketi”, 12 "Limited Şirket", 4 "Anonim Şirket" ve 3 "Diğer" başlığı altında gruplandığı tespit edilmiştir. İşletmeler faaliyet süresi açısından değerlendirildiğinde ilk sırayı 6-10 yıl süreyle faaliyet gösteren 21 işletme almakta olup bunu sırasıyla, 1-5 y1l süreyle faaliyet gösteren 19 işletme, 11-15 y1l süreyle faaliyet gösteren 14 işletme ve 16 yıl üstü süreyle faaliyet gösteren 8 işletme takip etmektedir. Konaklama işletmelerinde finansman bölümünün varlığına ilişkin soruya 46 işletme hayır yanıtı vermiş, 16 işletme ise evet yanıtı vermiştir. Konaklama işletmesinde finans yöneticiliğini kimin yaptığına ilişkin soruya 45 işletme tarafından "Patron, İşletme Sahibi” yanıtı verilmiş, bunu sırasıyla, 7 işletme "Diğer", 6 işletme "Muhasebe Müdürü" ve 4 işletme "Finans Müdürü" yanttları takip etmiştir. Konaklama işletmelerinde finansal plan yapılmasına ilişkin soruya 31 işletme "Evet", 31 işletme ise "Hayır" yanıtını vermiştir. 47 işletme özsermayelerini yeterli bulurken, 15 işletme özsermayelerini yetersiz bulmuşlardır. Konaklama işletmelerinde mevcut faaliyetlerin gerçekleştirilmesine ilişkin hangi finansman yönteminin kullanıldığı sorusuna ise, 41 işletme "Şirket Karı", 12 işletme "Banka Kredisi" ve 9 işletme "Özsermaye" yanıtını vermiştir.

Tablo 2: Konaklama İşletmelerinin Türüne Göre Finansal Sorunların Önem Düzeyi

\begin{tabular}{|c|c|c|c|c|}
\hline İşletme Türü & $\begin{array}{l}\text { Önem } \\
\text { Düzeyi }\end{array}$ & Finansal Sorunlar & Ortalama & $\begin{array}{c}\text { Standart } \\
\text { Sapma }\end{array}$ \\
\hline \multirow{6}{*}{ Otel } & \multirow{3}{*}{ Yüksek } & Kapasite düşüklüğü & 4,0769 & 1,03775 \\
\hline & & Kar marjlarının düşük olması & 4,0769 & 0,86232 \\
\hline & & Faizlerin yüksekliği & 4,0769 & 0,86232 \\
\hline & \multirow{3}{*}{ Düşük } & Nakit giriş ve çıkış zamanlamasındaki uyumsuzluk & 3,3846 & 1,04391 \\
\hline & & İşletme sermayesi yetersizliği & 3,2308 & 1,09193 \\
\hline & & Nakit açığı sorunu & 3,3077 & 0,85485 \\
\hline \multirow{6}{*}{ Butik Otel } & \multirow{3}{*}{ Yüksek } & Yüksek personel ve sigorta giderleri & 3,9333 & 1,11211 \\
\hline & & Yüksek vergi ve harçlar & 3,7333 & 1,36289 \\
\hline & & Sektörel teşviklerin yetersizliği & 3,6667 & 1,39786 \\
\hline & \multirow{3}{*}{ Düşük } & Mevzuatla ilgili yaşanan sorunlar & 2,9667 & 1,35146 \\
\hline & & Kredi kurumlarının yüksek teminat istemesi & 2,9333 & 1,17248 \\
\hline & & Kredi geri ödemelerinde ödemesiz sürenin yetersizliği & 2,8 & 1,18613 \\
\hline \multirow{6}{*}{ Pansiyon } & \multirow{3}{*}{ Yüksek } & Uygulanan ekonomi politikaları & 3,5625 & 0,89209 \\
\hline & & Yüksek vergi ve harçlar & 3,5625 & 1,09354 \\
\hline & & Kısıtlı kredi imkânları & 3,4375 & 1,36473 \\
\hline & \multirow{3}{*}{ Düşük } & İşletme sermayesi yetersizliği & 2,3125 & 1,07819 \\
\hline & & Nakit giriş ve çıkış zamanlamasındaki uyumsuzluk & 2,125 & 0,80623 \\
\hline & & Döviz kurlarında yaşanan dalgalanmalar & 2,0625 & 0,92871 \\
\hline \multirow{6}{*}{ Diğer } & \multirow{3}{*}{ Yüksek } & Öz sermaye yetersizliği & 4 & 0 \\
\hline & & Kapasite düşüklüğü & 3,6667 & 1,1547 \\
\hline & & Kar marjlarının düşük olması & 3,6667 & 1,1547 \\
\hline & \multirow{3}{*}{ Düşük } & Kredi geri ödemelerinde ödemesiz sürenin yetersizliği & 1,6667 & 1,1547 \\
\hline & & Kısıtlı kredi imkânları & 1,6667 & 1,1547 \\
\hline & & Döviz kurlarında yaşanan dalgalanmalar & 1,6667 & 1,1547 \\
\hline
\end{tabular}


Tablo 2'ye göre otellerin en önemli finansal sorunlarının kapasite düşüklügü, kar marjlarının düşük olması ve faizlerin yüksekliği olduğu görülmektedir. Nakit giriş ve çıkış zamanlamasındaki uyumsuzluk, işletme sermayesi yetersizliği ve nakit açığı sorunu otellerin finansal olarak önem düzeyi düşük sorunları olarak belirlenmiştir. Butik oteller açısından yüksek personel ve sigorta giderleri en önemli finansal sorun olarak görülmektedir. Kredi geri ödemelerinde ödemesiz sürenin yetersizliği ise butik oteller için finansal sorun olarak en düşük ortalamaya sahip olmuştur. Pansiyonlar için uygulanan ekonomi politikaları ile yüksek vergi ve harçlar sorunları en fazla ortalama değere sahip finansal sorunlar olurken, döviz kurlarında yaşanan dalgalanmalar en düşük ortalamaya sahip finansal sorun olarak tespit edilmiştir.

Tablo 3: Konaklama İşletmelerinin Belge Türüne Göre Finansal Sorunların Önem Düzeyi

\begin{tabular}{|c|c|c|c|c|}
\hline $\begin{array}{l}\text { Belge } \\
\text { Türü }\end{array}$ & $\begin{array}{l}\text { Önem } \\
\text { Düzeyi }\end{array}$ & Finansal Sorunlar & Ortalama & $\begin{array}{c}\text { Standart } \\
\text { Sapma }\end{array}$ \\
\hline \multirow{6}{*}{$\begin{array}{l}\text { Belediye } \\
\text { Belgeli }\end{array}$} & \multirow{3}{*}{ Yüksek } & Kapasite düşüklüğü & 3,5429 & 1,29121 \\
\hline & & Yüksek vergi ve harçlar & 3,5429 & 1,46213 \\
\hline & & Uygulanan ekonomi politikaları & 3,4286 & 1,19523 \\
\hline & \multirow{3}{*}{ Düşük } & Kredi geri ödemelerinde ödemesiz sürenin yetersizliği & 2,6571 & 1,32716 \\
\hline & & Nakit giriş ve çıkış zamanlamasındaki uyumsuzluk & 2,6571 & 1,18676 \\
\hline & & Kredi Kurumlarının yüksek teminat istemesi & 2,6 & 1,21752 \\
\hline \multirow{6}{*}{$\begin{array}{l}\text { Turizm } \\
\text { Bakanlığı } \\
\text { Belgeli }\end{array}$} & \multirow{3}{*}{ Yüksek } & Yüksek personel ve sigorta giderleri & 4,0741 & 1,10683 \\
\hline & & Sektörel teşviklerin yetersizliği & 3,8889 & 1,01274 \\
\hline & & Kar marjlarının düşük olması & 3,8148 & 1,14479 \\
\hline & \multirow{3}{*}{ Düşük } & İşletme sermayesi yetersizliği & 3,3333 & 1,27098 \\
\hline & & Döviz kurlarında yaşanan dalgalanmalar & 3,2963 & 1,17063 \\
\hline & & Kredi geri ödemelerinde ödemesiz sürenin yetersizliği & 3,037 & 0,97985 \\
\hline
\end{tabular}

Belediye Belgeli konaklama işletmelerinin karşılaştıkları finansal sorunlara bakıldığında en önemli finansal sorunların kapasite düşüklüğü ile yüksek vergi ve harçlar olduğu görülmektedir. Belediye Belgeli konaklama işletmeleri için kredi kurumlarının yüksek teminat istemesi en az öneme sahip finansal sorun olarak tespit edilmiştir. Turizm Bakanlığı Belgeli konaklama işletmelerinde yüksek personel ve sigorta giderleri önem düzeyi en yüksek finansal sorun iken, kredi geri ödemelerinde ödemesiz sürenin yetersizliği önem düzeyi en düşük finansal sorun olarak belirlenmiştir. 
Tablo 4: Konaklama İşletmelerinin Hukuki Yapılarına Göre Finansal Sorunların Önem Düzeyi

\begin{tabular}{|c|c|c|c|c|}
\hline $\begin{array}{c}\text { Hukuki } \\
\text { Yapı }\end{array}$ & $\begin{array}{l}\text { Önem } \\
\text { Düzeyi }\end{array}$ & Finansal Sorunlar & Ortalama & $\begin{array}{c}\text { Standart } \\
\text { Sapma }\end{array}$ \\
\hline \multirow{6}{*}{$\begin{array}{l}\text { Şahıs } \\
\text { Şirketi }\end{array}$} & \multirow{3}{*}{ Yüksek } & Yüksek vergi ve harçlar & 3,5814 & 1,31353 \\
\hline & & Kapasite düşüklüğü & 3,5581 & 1,2209 \\
\hline & & Uygulanan ekonomi politikaları & 3,4884 & 1,00882 \\
\hline & \multirow{3}{*}{ Düşük } & Kredi Kurumlarının yüksek teminat istemesi & 2,8605 & 1,16663 \\
\hline & & Nakit giriş ve çıkış zamanlamasındaki uyumsuzluk & 2,7907 & 1,26412 \\
\hline & & Kredi geri ödemelerinde ödemesiz sürenin yetersizliği & 2,7209 & 1,2017 \\
\hline \multirow{6}{*}{$\begin{array}{l}\text { Limited } \\
\text { Şirket }\end{array}$} & \multirow{3}{*}{ Yüksek } & Kısıtllı kredi imkânları & 4,25 & 0,86603 \\
\hline & & Uygulanan ekonomi politikaları & 4,25 & 0,86603 \\
\hline & & İş hayatına yönelik bürokratik engeller & 4,1667 & 1,2673 \\
\hline & \multirow{3}{*}{ Düşük } & Nakit giriş ve çıkış zamanlamasındaki uyumsuzluk & 3,4167 & 1,44338 \\
\hline & & Kredi Kurumlarının yüksek teminat istemesi & 3,3333 & 0,7785 \\
\hline & & Kapasite düşüklüğü & 3,25 & 1,3568 \\
\hline \multirow{6}{*}{$\begin{array}{l}\text { Anonim } \\
\text { Şirket }\end{array}$} & \multirow{3}{*}{ Yüksek } & Kar marjlarının düşük olması & 4,25 & 0,95743 \\
\hline & & Yüksek kredi maliyetleri & 4 & 1,1547 \\
\hline & & Kapasite düşüklüğü & 4 & 0,8165 \\
\hline & \multirow{3}{*}{ Düşük } & Alacakların zamanında tahsil edilememesi & 3,25 & 1,70783 \\
\hline & & Kredi geri ödemelerinde ödemesiz sürenin yetersizliği & 3 & 0,8165 \\
\hline & & İşletme sermayesi yetersizliği & 2,5 & 1,29099 \\
\hline \multirow{6}{*}{ Diğer } & \multirow{3}{*}{ En Çok } & Öz sermaye yetersizliği & 4 & 0 \\
\hline & & Kapasite düşüklüğü & 3,6667 & 1,1547 \\
\hline & & Mevzuatla ilgili yaşanan sorunlar & 3,6667 & 1,1547 \\
\hline & \multirow{3}{*}{ En Az } & Kredi Kurumlarının yüksek teminat istemesi & 1,6667 & 1,1547 \\
\hline & & Kredi geri ödemelerinde ödemesiz sürenin yetersizliği & 1,6667 & 1,1547 \\
\hline & & Nakit açı̆̆g sorunu & 1,6667 & 1,1547 \\
\hline
\end{tabular}

Yüksek vergi ve harçlar şahıs şirketi statüsündeki konaklama işletmeleri tarafindan en önemli görülen finansal sorun olurken, kısıtlı kredi imkânları ve uygulanan ekonomi politikaları limited şirketler tarafından, kar marjlarının düşük olması da anonim şirketler tarafından en önemli finansal sorunlar olarak görülmektedir. Kredi geri ödemelerinde ödemesiz sürenin yetersizliği şahıs şirketleri tarafindan en az önem düzeyine sahip finansal sorun olarak görülürken, limited şirket statüsündeki konaklama işletmeleri kapasite düşüklüğünü, anonim şirketler ise işletme sermayesi yetersizliğini en az önemli finansal sorun olarak gördüklerini belirtmişlerdir. 
Tablo 5: Konaklama İşletmelerinin Faaliyet Sürelerine Göre Finansal Sorunların Önem Düzeyi

\begin{tabular}{|c|c|c|c|c|}
\hline $\begin{array}{c}\text { Faaliyet } \\
\text { Süresi }\end{array}$ & $\begin{array}{l}\text { Önem } \\
\text { Düzeyi }\end{array}$ & Finansal Sorunlar & Ortalama & $\begin{array}{c}\text { Standart } \\
\text { Sapma }\end{array}$ \\
\hline \multirow{6}{*}{ 1-5 Yil } & \multirow{3}{*}{ Yüksek } & Kapasite düşüklüğü & 3,8421 & 1,21395 \\
\hline & & Sektörel teşviklerin yetersizliği & 3,8421 & 1,46299 \\
\hline & & Uygulanan ekonomi politikaları & 3,7895 & 1,35724 \\
\hline & \multirow{3}{*}{ Düşük } & Alacakların zamanında tahsil edilememesi & 3,0526 & 1,64903 \\
\hline & & Nakit giriş ve çıkış zamanlamasındaki uyumsuzluk & 3,0526 & 1,58021 \\
\hline & & Kredi vadelerinin k1sa olması & 3 & 1,52753 \\
\hline \multirow{6}{*}{ 6-10 Yil } & \multirow{3}{*}{ Yüksek } & Kısıtlı kredi imkânları & 3,7619 & 1,09109 \\
\hline & & Yüksek vergi ve harçlar & 3,7619 & 1,17918 \\
\hline & & İş hayatına yönelik bürokratik engeller & 3,7143 & 1,23056 \\
\hline & \multirow{3}{*}{ Düşük } & İşletme sermayesi yetersizliği & 2,8571 & 1,35225 \\
\hline & & Mevzuatla ilgili yaşanan sorunlar & 2,7619 & 1,13599 \\
\hline & & Nakit giriş ve çıkış zamanlamasındaki uyumsuzluk & 2,7143 & 1,0556 \\
\hline \multirow{6}{*}{ 11-15 Yll } & \multirow{3}{*}{ Yüksek } & Uygulanan ekonomi politikaları & 3,9286 & 1,14114 \\
\hline & & Kapasite düşüklüğü & 3,9286 & 0,99725 \\
\hline & & Yüksek vergi ve harçlar & 3,9286 & 1,32806 \\
\hline & \multirow{3}{*}{ Düşük } & Kısıtlı kredi imkânları & 2,8571 & 1,16732 \\
\hline & & Kredi geri ödemelerinde ödemesiz sürenin yetersizliği & 2,6429 & 0,92878 \\
\hline & & Kredi Kurumlarının yüksek teminat istemesi & 2,5000 & 0,75955 \\
\hline \multirow{6}{*}{$\begin{array}{l}16 \text { Yll ve } \\
\text { Üstü }\end{array}$} & \multirow{3}{*}{ Yüksek } & Yüksek personel ve sigorta giderleri & 3,6250 & 0,91613 \\
\hline & & Faizlerin yüksekliği & 3,6250 & 0,91613 \\
\hline & & Öz sermaye yetersizliği & 3,5000 & 1,06904 \\
\hline & \multirow{3}{*}{ Düşük } & Döviz kurlarında yaşanan dalgalanmalar & 2,8750 & 0,64087 \\
\hline & & Kısıtlı kredi imkânları & 2,7500 & 0,70711 \\
\hline & & Kredi geri ödemelerinde ödemesiz sürenin yetersizliği & 2,5000 & 0,75593 \\
\hline
\end{tabular}

1-5 yıl arası faaliyet gösteren konaklama işletmeleri için en önemli finansal sorunlar kapasite düşüklüğü ile sektörel teşviklerin yetersizliği olarak görülürken, 6-10 y1l arası faaliyet gösteren işletmeler k1sıtlı kredi imkanları ile yüksek vergi ve harçları, 11-15 yıl arası faaliyette bulunan işletmeler uygulanan ekonomi politikaları ile kapasite düşüklüğünü, 16 yıl ve daha fazla süredir faaliyet gösteren konaklama işletmeleri de yüksek personel ve sigorta giderleri ile faizlerin yüksekliğini en önemli finansal sorunlar olarak görmektedirler. 
Tablo 6: Konaklama İşletmelerinin Yatak Sayısına Göre Finansal Sorunların Önem Düzeyi

\begin{tabular}{|c|c|c|c|c|}
\hline $\begin{array}{l}\text { Yatak } \\
\text { Sayısı }\end{array}$ & $\begin{array}{l}\text { Önem } \\
\text { Düzeyi }\end{array}$ & Finansal Sorunlar & Ortalama & $\begin{array}{c}\text { Standart } \\
\text { Sapma }\end{array}$ \\
\hline \multirow{6}{*}{$\begin{array}{l}1-10 \\
\text { Yatak }\end{array}$} & \multirow{3}{*}{ Yüksek } & Yüksek vergi ve harçlar & 3,6429 & 1,39268 \\
\hline & & Faizlerin yüksekliği & 3,6429 & 1,39268 \\
\hline & & İş hayatına yönelik bürokratik engeller & 3,5714 & 1,39859 \\
\hline & \multirow{3}{*}{ Düşük } & Döviz kurlarında yaşanan dalgalanmalar & 2,6429 & 1,44686 \\
\hline & & İşletme sermayesi yetersizliği & 2,6429 & 1,44686 \\
\hline & & Nakit giriş ve çıkış zamanlamasındaki uyumsuzluk & 2,5 & 1,34450 \\
\hline \multirow{6}{*}{$\begin{array}{l}11-20 \\
\text { Yatak }\end{array}$} & \multirow{3}{*}{ Yüksek } & Kapasite Düşüklüğü & 3,7619 & 1,04426 \\
\hline & & Sektörel teşviklerin yetersizliği & 3,7143 & 1,10195 \\
\hline & & Yüksek personel ve sigorta giderleri & 3,5714 & 1,28730 \\
\hline & \multirow{3}{*}{ Düşük } & Nakit giriş ve çıkış zamanlamasındaki uyumsuzluk & 2,7143 & 0,90238 \\
\hline & & Kredi Kurumlarının yüksek teminat istemesi & 2,6190 & 1,11697 \\
\hline & & Kredi geri ödemelerinde ödemesiz sürenin yetersizliği & 2,3333 & 1,23828 \\
\hline \multirow{6}{*}{$\begin{array}{l}21-30 \\
\text { Yatak }\end{array}$} & \multirow{3}{*}{ Yüksek } & Yüksek vergi ve harçlar & 3,9167 & 1,50504 \\
\hline & & Kapasite Düşüklüğü & 3,8333 & 1,26730 \\
\hline & & Sektörel teşviklerin yetersizliği & 3,75 & 1,48477 \\
\hline & \multirow{3}{*}{ Düşük } & Kredi Kurumlarının yüksek teminat istemesi & 3,0833 & 1,08362 \\
\hline & & Kredi geri ödemelerinde ödemesiz sürenin yetersizliği & 3,0833 & 0,99620 \\
\hline & & Mevzuatla ilgili yaşanan sorunlar & 3,0833 & 1,37895 \\
\hline \multirow{6}{*}{$\begin{array}{l}31-40 \\
\text { Yatak }\end{array}$} & \multirow{3}{*}{ Yüksek } & Kısıtlı kredi imkânları & 4,5 & 1 \\
\hline & & Uygulanan ekonomi politikaları & 4,5 & 0,57735 \\
\hline & & Girdi maliyetlerinin yüksekliği & 4,5 & 0,57735 \\
\hline & \multirow{3}{*}{ Düşük } & Kapasite Düşüklüğü & 2,75 & 1,70783 \\
\hline & & Mevzuatla ilgili yaşanan sorunlar & 2,5 & 1,73205 \\
\hline & & Döviz kurlarında yaşanan dalgalanmalar & 2,25 & 1,5 \\
\hline \multirow{6}{*}{$\begin{array}{l}41 \text { Yatak } \\
\text { ve Üstü }\end{array}$} & \multirow{3}{*}{ Yüksek } & Sektörel teşviklerin yetersizliği & 4,1818 & 0,87386 \\
\hline & & İş hayatına yönelik bürokratik engeller & 4 & 0,89443 \\
\hline & & Yüksek personel ve sigorta giderleri & 4 & 1,09545 \\
\hline & \multirow{3}{*}{ Düşük } & Nakit giriş ve çıkış zamanlamasındaki uyumsuzluk & 3,5455 & 1,36848 \\
\hline & & İşletme sermayesi yetersizliği & 3,4545 & 1,50756 \\
\hline & & Kredi geri ödemelerinde ödemesiz sürenin yetersizliği & 3,2727 & 1,00905 \\
\hline
\end{tabular}

Konaklama işletmelerinin yatak sayısı değişkeni kapsamında belirlenen finansal sorunlarının önem düzeyi yüksek olanlarının genel olarak yüksek vergi ve harçlar, yüksek personel ve sigorta giderleri, sektörel teşviklerin yetersizliği ve kapasite düşüklüğü olduğu görülmektedir. Bu kapsamda nakit giriş ve çıkış zamanlamasındaki uyumsuzluk, işletme sermayesi yetersizliği ve kredi geri ödemelerinde ödemesiz sürenin yetersizliği sorunları işletmelerin önem düzeyi düşük finansal sorunları olarak tespit edilmiştir. 
Tablo 7: Konaklama İşletmelerinin Personel Sayılarına Göre Finansal Sorunların Önem Düzeyi

\begin{tabular}{|c|c|c|c|c|}
\hline $\begin{array}{c}\text { Personel } \\
\text { Sayısı }\end{array}$ & $\begin{array}{l}\text { Önem } \\
\text { Düzeyi }\end{array}$ & Finansal Sorunlar & Ortalama & $\begin{array}{c}\text { Standart } \\
\text { Sapma }\end{array}$ \\
\hline \multirow{6}{*}{$\begin{array}{l}1-9 \\
\text { Personel }\end{array}$} & \multirow{3}{*}{ Yüksek } & Yüksek vergi ve harçlar & 3,5660 & 1,36592 \\
\hline & & Sektörel teşviklerin yetersizliği & 3,5472 & 1,29446 \\
\hline & & Yüksek personel ve sigorta giderleri & 3,5472 & 1,35258 \\
\hline & \multirow{3}{*}{ Düşük } & Nakit giriş ve çıkış zamanlamasındaki uyumsuzluk & 2,8491 & 1,27696 \\
\hline & & Kredi Kurumlarının yüksek teminat istemesi & 2,8113 & 1,14450 \\
\hline & & Kredi geri ödemelerinde ödemesiz sürenin yetersizliği & 2,6981 & 1,18622 \\
\hline \multirow{6}{*}{$\begin{array}{l}\text { 10-20 } \\
\text { Personel }\end{array}$} & \multirow{3}{*}{ Yüksek } & Kapasite düşüklüğü & 4,6 & 0,54772 \\
\hline & & İş hayatına yönelik bürokratik engeller & 4,6 & 0,54772 \\
\hline & & Mevzuatla ilgili yaşanan sorunlar & 4,4 & 0,54772 \\
\hline & \multirow{3}{*}{ Düşük } & Döviz kurlarında yaşanan dalgalanmalar & 3,4 & 1,14018 \\
\hline & & Yüksek personel ve sigorta giderleri & 3,4 & 1,51658 \\
\hline & & Girdi maliyetlerinin yüksekliği & 3,4 & 1,51658 \\
\hline \multirow{6}{*}{$\begin{array}{l}\text { 21-30 } \\
\text { Personel }\end{array}$} & \multirow{3}{*}{ Yüksek } & Yüksek vergi ve harçlar & 4 & 1,41421 \\
\hline & & Yüksek personel ve sigorta giderleri & 4 & 1,41421 \\
\hline & & Yüksek kredi maliyetleri & 3,5 & 0,70711 \\
\hline & \multirow{3}{*}{ Düşük } & İşletme sermayesi yetersizliği & 3 & 0 \\
\hline & & Nakit giriş ve çıkış zamanlamasındaki uyumsuzluk & 3 & 0 \\
\hline & & Kredi geri ödemelerinde ödemesiz sürenin yetersizliği & 2,5 & 0,70711 \\
\hline \multirow{6}{*}{$\begin{array}{l}31 \text { ve Üstü } \\
\text { Personel }\end{array}$} & \multirow{3}{*}{ Yüksek } & Kredi Kurumlarının yüksek teminat istemesi & 4,5 & 0,70711 \\
\hline & & Yüksek kredi maliyetleri & 4 & 1,41421 \\
\hline & & Kısitlı kredi imkânları & 4 & 1,41421 \\
\hline & \multirow{3}{*}{ Düşük } & Faizlerin yüksekliği & 3,5 & 0,70711 \\
\hline & & Nakit giriş ve çıkış zamanlamasındaki uyumsuzluk & 3 & 1,41421 \\
\hline & & İşletme sermayesi yetersizliği & 2,5 & 2,12132 \\
\hline
\end{tabular}

Konaklama işletmelerinin personel sayısı dikkate alındığında karşılaşılan finansal sorunların önem düzeyi yüksek olanlarının genel olarak yüksek vergi ve harçlar, yüksek personel ve sigorta giderleri ile yüksek kredi maliyetleri olduğu görülmektedir. Bu doğrultuda nakit giriş ve çıkış zamanlamasındaki uyumsuzluk, işletme sermayesi yetersizliği ve kredi geri ödemelerinde ödemesiz sürenin yetersizliği sorunları işletmelerin önem düzeyi düşük finansal sorunları olarak tespit edilmiştir. 
Tablo 8: Konaklama İşletmelerinde Finansman Bölümünün Varlığına Göre Finansal Sorunların Önem Düzeyi

\begin{tabular}{|c|c|c|c|c|}
\hline $\begin{array}{c}\text { Finansman } \\
\text { Bölümü }\end{array}$ & $\begin{array}{l}\text { Önem } \\
\text { Düzeyi }\end{array}$ & Finansal Sorunlar & Ortalama & $\begin{array}{c}\text { Standart } \\
\text { Sapma }\end{array}$ \\
\hline \multirow{6}{*}{ Evet } & \multirow{3}{*}{ Yüksek } & Öz sermaye yetersizliği & 4 & 1,1547 \\
\hline & & Alacakların zamanında tahsil edilememesi & 3,75 & 1,18322 \\
\hline & & Kar marjlarının düşük olması & 3,6875 & 1,30224 \\
\hline & \multirow{3}{*}{ Düşük } & Döviz kurlarında yaşanan dalgalanmalar & 3,0625 & 1,48183 \\
\hline & & Kredi Kurumlarının yüksek teminat istemesi & 2,875 & 1,36015 \\
\hline & & Kredi geri ödemelerinde ödemesiz sürenin yetersizliği & 2,875 & 1,36015 \\
\hline \multirow{6}{*}{ Hayır } & \multirow{3}{*}{ Yüksek } & Sektörel teşviklerin yetersizliği & 3,7391 & 1,21901 \\
\hline & & Yüksek vergi ve harçlar & 3,6739 & 1,28330 \\
\hline & & Kapasite Düşüklüğü & 3,6522 & 1,13954 \\
\hline & \multirow{3}{*}{ Düşük } & Alacakların zamanında tahsil edilememesi & 2,9348 & 1,37279 \\
\hline & & Nakit giriş ve çıkış zamanlamasındaki uyumsuzluk & 2,8696 & 1,25802 \\
\hline & & Kredi geri ödemelerinde ödemesiz sürenin yetersizliği & 2,8043 & 1,14736 \\
\hline
\end{tabular}

Tablo 8 incelendiğinde bünyesinde finansman bölümü bulunan konaklama işletmelerinin finansal sorun olarak öz sermaye yetersizliğini ön plana çıkardıkları görülmektedir. Bünyesinde finansman bölümü bulunmayan konaklama işletmelerinde ise sektörel teşviklerin yetersizliği en yüksek ortalamaya sahip finansal sorun olarak belirlenmiştir. Her iki tür konaklama işletmesi için de kredi geri ödemelerinde ödemesiz sürenin yetersizliği önem derecesi en düşük finansal sorun olarak görülmektedir.

Tablo 9: Konaklama İşletmelerinde Finans Yönetimi Faaliyetinin Sorumlusuna Göre Finansal Sorunların Önem Düzeyi

\begin{tabular}{|c|c|c|c|c|}
\hline Sorumlu & $\begin{array}{l}\text { Önem } \\
\text { Düzeyi }\end{array}$ & Finansal Sorunlar & Ortalama & $\begin{array}{c}\text { Standart } \\
\text { Sapma }\end{array}$ \\
\hline \multirow{6}{*}{$\begin{array}{l}\text { Patron/ } \\
\text { İssletme } \\
\text { Sahibi }\end{array}$} & \multirow{3}{*}{ Yüksek } & Yüksek personel ve sigorta giderleri & 3,8 & 1,15994 \\
\hline & & Sektörel teşviklerin yetersizliği & 3,7556 & 1,13128 \\
\hline & & Yüksek vergi ve harçlar & 3,7111 & 1,23624 \\
\hline & \multirow{3}{*}{ Düşük } & Kredi Kurumlarının yüksek teminat istemesi & 3,0667 & 1,03133 \\
\hline & & Nakit giriş ve çıkış zamanlamasındaki uyumsuzluk & 2,9111 & 1,27604 \\
\hline & & Kredi geri ödemelerinde ödemesiz sürenin yetersizliği & 2,7778 & 1,10554 \\
\hline \multirow{6}{*}{$\begin{array}{l}\text { Finans } \\
\text { Müdürü/ } \\
\text { Finansman } \\
\text { Bölümü }\end{array}$} & \multirow{3}{*}{ Yüksek } & Kar marjlarının düşük olması & 4,75 & 0,5 \\
\hline & & Kısıtlı kredi imkânları & 4,5 & 0,57735 \\
\hline & & Kredi vadelerinin kısa olmas1 & 4,5 & 0,57735 \\
\hline & \multirow{3}{*}{ Düşük } & Sektörel teşviklerin yetersizliği & 3 & 1,1547 \\
\hline & & Döviz kurlarında yaşanan dalgalanmalar & 3 & 1,82574 \\
\hline & & Kapasite düşüklüğ̈̈ & 2,5 & 1,29099 \\
\hline
\end{tabular}




\begin{tabular}{|c|c|c|c|c|}
\hline Sorumlu & $\begin{array}{l}\text { Önem } \\
\text { Düzeyi }\end{array}$ & Finansal Sorunlar & Ortalama & $\begin{array}{c}\text { Standart } \\
\text { Sapma }\end{array}$ \\
\hline \multirow{6}{*}{$\begin{array}{l}\text { Muhasebe } \\
\text { Müdürü/ } \\
\text { Muhasebe } \\
\text { Bölümü }\end{array}$} & \multirow{3}{*}{ Yüksek } & Öz sermaye yetersizliği & 4 & 0,89443 \\
\hline & & Kapasite düşüklüğü & 3,6667 & 0,81650 \\
\hline & & Girdi maliyetlerinin yüksekliği & 3,6667 & 1,03280 \\
\hline & \multirow{3}{*}{ Düşük } & Kısıtlı kredi imkânları & 2,3333 & 1,50555 \\
\hline & & Kredi Kurumlarının yüksek teminat istemesi & 2,1667 & 1,83485 \\
\hline & & Döviz kurlarında yaşanan dalgalanmalar & 2,1667 & 1,32916 \\
\hline \multirow{6}{*}{ Diğer } & \multirow{3}{*}{ Yüksek } & Sektörel teşviklerin yetersizliği & 3,7143 & 1,88982 \\
\hline & & Yüksek vergi ve harçlar & 3,7143 & 1,88982 \\
\hline & & Kapasite düşüklüğü & 3,5714 & 1,61835 \\
\hline & \multirow{3}{*}{ Düşük } & Mevzuatla ilgili yaşanan sorunlar & 2,2857 & 1,38013 \\
\hline & & İşletme sermayesi yetersizliği & 2,1429 & 1,46385 \\
\hline & & Alacakların zamanında tahsil edilememesi & 2 & 1,73205 \\
\hline
\end{tabular}

Konaklama işletmelerinde finans yönetimi faaliyetini yürüten yetkililer açısından finansal sorunlara bakıldığında patron/işletme sahibinin yetkili olduğu işletmelerde yüksek personel ve sigorta giderleri; finans müdürünün yetkili olduğu işletmelerde kar marjlarının düşük olması; muhasebe müdürünün yetkili olduğu işletmelerde öz sermaye yetersizliği ve diğer personelin sorumlu olduğu işletmelerde ise sektörel teşviklerin yetersizliği ile yüksek vergi ve harçlar en önemli finansal sorun olarak ifade edilmiştir.

\section{Tablo 10: Konaklama İşletmelerinde Finansal Planlamanın Yapılıp Yapılmamasına Göre Finansal} Sorunların Önem Düzeyi

\begin{tabular}{|c|c|c|c|c|}
\hline $\begin{array}{c}\text { Finansal } \\
\text { Plan } \\
\end{array}$ & $\begin{array}{l}\text { Önem } \\
\text { Düzeyi }\end{array}$ & Finansal Sorunlar & Ortalama & $\begin{array}{c}\text { Standart } \\
\text { Sapma }\end{array}$ \\
\hline \multirow{6}{*}{ Evet } & \multirow{3}{*}{ Yüksek } & Yüksek personel ve sigorta giderleri & 3,9677 & 1,16859 \\
\hline & & Yüksek vergi ve harçlar & 3,9032 & 1,19317 \\
\hline & & Sektörel teşviklerin yetersizliği & 3,7742 & 1,20304 \\
\hline & \multirow{3}{*}{ Düşük } & Nakit giriş ve çıkış zamanlamasındaki uyumsuzluk & 3,1290 & 1,43159 \\
\hline & & Kredi geri ödemelerinde ödemesiz sürenin yetersizliği & 3,0645 & 1,23654 \\
\hline & & Kredi kurumlarının yüksek teminat istemesi & 3 & 1,06458 \\
\hline \multirow{6}{*}{ Hayır } & \multirow{3}{*}{ Yüksek } & Kar marjlarının düşük olması & 3,4839 & 0,99569 \\
\hline & & Uygulanan ekonomi politikaları & 3,4516 & 1,05952 \\
\hline & & Sektörel teşviklerin yetersizliği & 3,4516 & 1,26065 \\
\hline & \multirow{3}{*}{ Düşük } & Nakit giriş ve çıkış zamanlamasındaki uyumsuzluk & 2,8065 & 1,10813 \\
\hline & & Döviz kurlarında yaşanan dalgalanmalar & 2,7419 & 1,38967 \\
\hline & & Kredi geri ödemelerinde ödemesiz sürenin yetersizliği & 2,5806 & 1,11876 \\
\hline
\end{tabular}

Tablo 10'da finansal planlama yapan ve yapmayan konaklama işletmelerinin finansal sorunlarına ilişkin ortalamalar ve buna bağlı olarak sorunların önem düzeyi verilmiştir. Finansal planlama yapan konaklama işletmeleri için en yüksek ortalamaya sahip sorun yüksek personel ve sigorta giderleri iken ikinci sırada yüksek vergi ve harçlar yer almaktadır. Finansal planlama yapmayan konaklama işletmeleri için ise en yüksek ortalamaya sahip sorun kar marjlarının düşük olması iken bu sorunu uygulanan ekonomi politikaları ve sektörel 
teşviklerin yetersizliği takip etmektedir. Finansal planlama yapan konaklama işletmeleri için en düşük ortalamaya sahip finansal sorun kredi kurumlarının yüksek teminat istemesi iken finansal planlama yapmayan konaklama işletmeleri için en düşük ortalamaya sahip finansal sorun kredi geri ödemelerinde ödemesiz sürenin yetersizliğidir.

Tablo 11: Konaklama İşletmelerinin Özsermayelerinin Yeterli Olup Olmamasına Göre Finansal Sorunların Önem Düzeyi

\begin{tabular}{|c|c|c|c|c|}
\hline $\begin{array}{c}\text { Özsermaye } \\
\text { Yeterliliği }\end{array}$ & $\begin{array}{l}\text { Önem } \\
\text { Düzeyi }\end{array}$ & Finansal Sorunlar & Ortalama & $\begin{array}{c}\text { Standart } \\
\text { Sapma }\end{array}$ \\
\hline \multirow{6}{*}{ Evet } & \multirow{3}{*}{ Yüksek } & Sektörel teşviklerin yetersizliği & 3,8723 & 1,09578 \\
\hline & & Yüksek vergi ve harçlar & 3,8723 & 1,22682 \\
\hline & & Uygulanan ekonomi politikaları & 3,6809 & 1,14410 \\
\hline & \multirow{3}{*}{ Düşük } & Nakit giriş ve çıkış zamanlamasındaki uyumsuzluk & 2,8936 & 1,28932 \\
\hline & & Kredi Kurumlarının yüksek teminat istemesi & 2,8723 & 1,03456 \\
\hline & & Kredi geri ödemelerinde ödemesiz sürenin yetersizliği & 2,8298 & 1,22153 \\
\hline \multirow{6}{*}{ Hayır } & \multirow{3}{*}{ Yüksek } & Öz sermaye yetersizliği & 3,6667 & 1,23443 \\
\hline & & Yüksek personel ve sigorta giderleri & 3,6 & 1,24212 \\
\hline & & Faizlerin yüksekliği & 3,4667 & 1,0601 \\
\hline & \multirow{3}{*}{ Düşük } & Kredi geri ödemelerinde ödemesiz sürenin yetersizliği & 2,8 & 1,14642 \\
\hline & & Sektörel teşviklerin yetersizliği & 2,8 & 1,32017 \\
\hline & & Mevzuatla ilgili yaşanan sorunlar & 2,5333 & 1,24595 \\
\hline
\end{tabular}

Tablo 11 incelendiğinde özsermayesinin yeterli olduğunu belirten konaklama işletmelerinin finansal sorun olarak sektörel teşviklerin yetersizliği ile yüksek vergi ve harçları ön plana çıkardıkları görülmektedir. Özsermayesinin yetersiz olduğunu belirten konaklama işletmelerinde ise özsermaye yetersizliği en yüksek ortalamaya sahip finansal sorun olarak belirlenmiştir.

Tablo 12: Konaklama İşletmelerinde Faaliyetlerin Finansman Kaynaklarına Göre Finansal Sorunların Önem Düzeyi

\begin{tabular}{|c|c|c|c|c|}
\hline $\begin{array}{c}\text { Finansman } \\
\text { Kaynağı }\end{array}$ & $\begin{array}{c}\text { Önem } \\
\text { Düzeyi }\end{array}$ & Finansal Sorunlar & Ortalama & $\begin{array}{c}\text { Standart } \\
\text { Sapma }\end{array}$ \\
\hline \multirow{6}{*}{ Şirket Karı } & \multirow{3}{*}{ Yüksek } & Sektörel teşviklerin yetersizliği & 3,8780 & 1,07692 \\
\hline & & Yüksek vergi ve harçlar & 3,8780 & 1,05345 \\
\hline & & Kapasite düşüklüğü & 3,6829 & 1,19246 \\
\hline & \multirow{3}{*}{ Düşük } & Alacakların zamanında tahsil edilememesi & 3,0244 & 1,40513 \\
\hline & & Kredi geri ödemelerinde ödemesiz sürenin yetersizliği & 3 & 1,24499 \\
\hline & & Nakit giriş ve çıkış zamanlamasındaki uyumsuzluk & 2,8537 & 1,17390 \\
\hline \multirow{6}{*}{$\begin{array}{l}\text { Banka } \\
\text { Kredisi }\end{array}$} & \multirow{3}{*}{ Yüksek } & Öz sermaye yetersizliği & 3,8333 & 1,26730 \\
\hline & & Yüksek personel ve sigorta giderleri & 3,8333 & 1,33712 \\
\hline & & Alacakların zamanında tahsil edilememesi & 3,75 & 1,28806 \\
\hline & \multirow{3}{*}{ Düşük } & Kredi geri ödemelerinde ödemesiz sürenin yetersizliği & 2,6667 & 1,07309 \\
\hline & & Sektörel teşviklerin yetersizliği & 2,5833 & 1,24011 \\
\hline & & Mevzuatla ilgili yaşanan sorunlar & 2,4167 & 1,37895 \\
\hline
\end{tabular}




\begin{tabular}{|c|c|c|c|c|}
\hline $\begin{array}{c}\text { Finansman } \\
\text { Kaynağı }\end{array}$ & $\begin{array}{l}\text { Önem } \\
\text { Düzeyi }\end{array}$ & Finansal Sorunlar & Ortalama & $\begin{array}{c}\text { Standart } \\
\text { Sapma } \\
\end{array}$ \\
\hline \multirow{6}{*}{ Öz Sermaye } & \multirow{3}{*}{ Yüksek } & Sektörel teşviklerin yetersizliği & 3,7778 & 1,30171 \\
\hline & & Kapasite düşüklüğü & 3,6667 & 0,86603 \\
\hline & & Uygulanan ekonomi politikaları & 3,5556 & 1,66667 \\
\hline & \multirow{3}{*}{ Düşük } & Döviz kurlarında yaşanan dalgalanmalar & 2,3333 & 1,41421 \\
\hline & & Kredi Kurumlarının yüksek teminat istemesi & 2,2222 & 0,97183 \\
\hline & & Kredi geri ödemelerinde ödemesiz sürenin yetersizliği & 2,2222 & 0,97183 \\
\hline
\end{tabular}

Faaliyetlerin finansmanında şirket karı ve özsermayeyi kullanan konaklama işletmeleri için en önemli finansal sorun sektörel teşviklerin yetersizliği olurken, faaliyetlerin finansmanında banka kredisini kullanan konaklama işletmeleri için en önemli finansal sorunlar ise öz sermaye yetersizliği ile yüksek personel ve sigorta giderleridir. Farklı finansman kaynaklarını kullanan konaklama işletmeleri kredi geri ödemelerinde ödemesiz sürenin yetersizliğini en az önemli finansal sorunlardan biri olarak gördüklerini belirtmişlerdir.

\section{SONUÇ}

Turizm sektörü, gelir yaratan, döviz girişi ve istihdam imkanı sağlayan, sosyal ve kültürel hayata etki eden önemli bir sektör niteliği taşımaktadır. Sektörün temelini oluşturan turizm işletmelerinin ekonomik, siyasi ve sosyal gelişmelerden etkilenmesi bu işletmelerin sağlıklı bir mali yapıya sahip olmalarını gerekli kılmaktadır. Dolayısıyla sürekli gelişen ve büyüyen turizm sektörü içinde faaliyet gösteren konaklama işletmelerinin sağlıklı bir mali yapıya sahip olması üzerinde dikkatle durulması gereken bir konudur.

Bu çalışmada turizm sektöründeki önemli destinasyonlardan biri olan Safranbolu'da yer alan konaklama işletmelerinin finansal sorunlarının tespit edilmesi amaçlanmıştır. Bu amaç doğrultusunda Safranbolu'da yer alan konaklama işletmelerine anket uygulanmış ve elde edilen veriler ile frekans analizi yapılmıştır.

Çalışmada, Safranbolu ilçesindeki konaklama işletmeleri farklı açılardan ele alındığında bu işletmelerin karşılaştıkları finansal sorunların değişkenlik gösterdiği belirlenmiştir. Buna göre genel olarak önem düzeyi yüksek olarak görülen ve sıklıkla karşılaşılan finansal sorunların kapasite düşüklüğü, yüksek personel ve sigorta giderleri, kar marjlarının düşük olması, özsermaye yetersizliği, kısıtlı kredi imkanları, yüksek vergi ve harçlar ile sektörel teşviklerin yetersizliği olduğu tespit edilmiştir.

Araştırma kapsamındaki konaklama işletmelerinin 47'si 30 ve altında yatak sayısına sahiptir. Dolayısıyla Safranbolu'daki konaklama işletmelerinin genelinin kapasite açısından büyük işletmeler olmaması, daha çok ailelerce işletilmesi ve buna bağlı olarak da az sayıda çalışanın olması nedeniyle bu işletmeler ayrı bir finansman bölümüne sahip değillerdir. Bu durum konaklama işletmelerinin ihtiyaç duyduğu fonların doğru kaynaklardan elde edilmesini engelleyebilmekte ve finansman konusunda karşılaşılan sorunlara ilişkin rasyonel çözüm önerileri sunulamamasına neden olmaktadır. Ayrıca finansal ürün çeşitliliğinin ve risk kaynaklarının sürekli arttığı bir ekonomik ortamda faaliyette bulunan işletmelerin söz konusu riskleri tespit edip buna göre pozisyon alacak finansal konularda uzman insan kaynağına ihtiyaç olduğu görülmektedir. Dolayısıyla işletmelerin yapısı gereği ayrı bir finansman bölümü olmasa bile finansal konularda eğitimli ve deneyimli personelin istihdam edilmesi finansal nitelikli sorunların üstesinden gelinmesinde yardımcı olabilecektir.

Analize dahil edilen konaklama işletmelerinin \%50'si finansal planlama yapmadığını belirtmiştir. Faaliyetlerin önceden plana bağlanması işletme yönetici veya sahiplerinin karar verme aşamasında işini kolaylaştırmakla beraber beklenmedik durumlar karşısında hazırlıklı olmayı da sağlamaktadır. Dolayısıyla işletmelerin finansal planlamayı iş süreçlerinin zorunlu bir parçası olarak görmeleri finansal nitelikli sorunların aşılmasında kolaylık sağlayacaktır. Özellikle birçok işletmenin başarısızlığa uğramasında nakit dengesinin sağlanamamasının rol oynaması göz önünde bulundurulduğunda işletmelerin en azından dönemsel nakit bütçesi hazırlamaları büyük önem arz etmektedir. Bu kapsamda finansal kiralama, faktoring gibi gelişen finansal araçlardan yararlanmak suretiyle nakit yönetimi ve tahsilatta yaşanan sorunlarla başa çıkılabilecektir. Ayrıca işletme sahip ve/veya yöneticilerinin belirli periyotlarla gerçekleştirecekleri finansal analizler işletmenin hangi yönlerden zayıf hangi yönlerden güçlü olduğunu ortaya koyacak ve bu doğrultuda gerekli adımlar atılabilecektir.

Çalışmada ulaşılan sonuçlar turizm sektöründe faaliyet gösteren konaklama işletmelerinin yöneticilerine, araştırmacılara ve ilgili kamu kurumlarına konaklama işletmelerinin finansal sorunları hakkında bilgi 
sağlamaktadır. Ayrıca çalışmada elde edilen sonuçlar, ileride Safranbolu'da yapılabilecek yeni araştırma sonuçları ile kıyaslanabilir ve zaman içinde mevcut finansal sorunların ne ölçüde değişim gösterdiği tespit edilebilecektir. 


\section{KAYNAKÇA}

Akay, B., Sancar, M. F., Uslu, A. ve Öztürk, B. (2015) “Turizm İşletmelerinin Finansal Sorunları ve Çözüm Önerileri”, Journal of Recreation and Tourism Research, 2(2), s. 27-33.

Akıncı, Z. (2016) Otel İşletmeciliği ve Yönetimi, Detay Yayıncılık, Ankara.

Bilen, A., Karakaş, A. ve Yağmur, M. (2014) "Diyarbakır'daki Yerleşik Konaklama İşletmelerinin Karşılaştığı Finansal Sorunlar ve Çözüm Önerileri”, Bartın Üniversitesi İ.İ.B.F. Dergisi, 5(10), s. 91-104.

Ceylan, A. ve İlban, M. O. (2005) "Otel İşletmelerinin Finansal Sorunları Balıkesir İlinde Bir Alan Araştırması”, Seyahat ve Otel işletmeciliği Dergisi, 2(3), s. 12-18.

Karadeniz, E., Unur, K., Köşker, H. ve Zencir, B. (2015) "Van İlinde Faaliyet Gösteren KOBİ Statüsündeki Konaklama ve Seyahat İşletmelerinin Finansal Sorunlarının Analizi”, Ç.Ü. Sosyal Bilimler Enstitüsü Dergisi, 24(1), s. 85-98.

Karadeniz, E., Koşan, L. ve Geçgin, E. (2018) "KOBİ Kapsamındaki Otel İşletmelerinin Finansal Sorunları: Kars ve Erzurum İllerinde Bir Araştırma", Seyahat ve Otel İşletmeciliği Dergisi, 15(2), s. 302-319.

Kaşl1, M. ve Karataban, Ö. (2008) “İstanbul Menkul Kıymetler Borsası'nda İşlem Gören Turizm İşletmelerinin Oranlar Yoluyla Analizi”, 3. Balıkesir Ulusal Turizm Kongresi, 17-19 Nisan 2008, Balıkesir.

Sanjeev, G. M., Gupta, K. ve Bandyopadhyay, R. (2012) "Financial Challenges in The Indian Hospitality Industry", Worldwide Hospitality and Tourism Themes, 4(2), s. 163-173.

STDB (2019) "Safranbolu Turizm Danışma Bürosu- Konaklama Tesisleri”, Güncelleme tarihi: 12.05.2019, http://www.safranboluturizmdanismaburosu.gov.tr/TR-156254/konaklama---yeme-icme.html.

Türksoy, A. (2007) "Konaklama İşletmelerinde Mali Başarısızlığa Yol Açan Etmenler”, Ege Akademik Bakış, 7(1), s. 99-115.

Ünüvar, Ş. (2006) “Pazarlama Aracı Olarak Konaklama İşletmelerinde Halkla İlişkiler Faaliyetleri”, Selçuk Üniversitesi Sosyal Bilimler Meslek Yüksekokulu Dergisi, 9(1-2), s. 179-198.

Yılmaz, H. (2007) “Turizm Sektörü KOBİ’lerinin Finansman Sorunlarının Diğer Sektörlerle Karşılaştırmalı Analizi: Bodrum Örneği”, Muhasebe ve Finansman Dergisi, 33, s. 162-170. 